\title{
Influence of irrigation, planting density and vegetative propagation on yield of rhizomes of arrowroot starch
}

\section{Influência da irrigação, densidade de plantio e propagação vegetativa na produtividade de rizomas e fécula da araruta}

\author{
Douglas C. de Souza*, Luis F. L. Silva, Luciane V. Resende, Paula A. Costa, Thiago S. Guerra \\ and Wilson M. Gonçalves
}

Departamento de Agricultura/Universidade Federal de Lavras (UFLA), Campus Universitário, 37200-000, Lavras, MG, Brasil

( ${ }^{*}$ E-mail:douglascorrea@ymail.com)

http://dx.doi.org/10.19084/RCA18015

Received/recebido: 2018.01.18

Received in revised form/recebido em versão revista: 2018.04.02

Accepted/aceite: 2018.05.11

\begin{abstract}
A B S T R A C T
The arrowroot is considered a non-conventional vegetable which has aroused interest in the food industry because of its starch content with differentiated characteristics and high commercial value. However, agronomic management information is scarce, making it difficult to compete with other species of similar purpose, and more studies are needed regarding the crop. The aim of this study was to define adequate agronomic practices in crop aiming the productivity the rhizome, yield the starch of arrowroot. The factors evaluated were the different levels of irrigation, the planting and the plant densities. The randomized block design was used in the field trial while the totally randomized block design was used in the laboratory tests. Through the treatments, crop yield ranged from 0.68 (seedlings; without irrigation; 31250 plants ha-1) to $60.09 \mathrm{t} \mathrm{ha}^{-1}$ (seedlings; irrigated; 31250 plants ha-1), while starch production ranged from 50 to $6350 \mathrm{~kg} \mathrm{ha}^{-1}$. The highest yield of rhizomes was obtained in plants produced by seedlings along with the highest density of plants, and the highest production of arrowroot starch was extracted from rhizomes from plants produced by seedlings without irrigation and a density of 50000 plants ha-1.
\end{abstract}

Keywords: Maranta arundinacea L., non-conventional vegetables, starch, rescue.

\section{R E S U M O}

A araruta é considerada uma hortaliça não convencional que vem despertando interesse da indústria alimentícia em virtude de seu amido, com características diferenciadas e elevado valor comercial. Contudo, são escassas as informações quanto ao manejo agronómico, dificultando sua competição comercial com outras espécies de finalidade semelhante, sendo necessários mais estudos com a cultura. Diante disso, objetivou-se definir práticas adequadas de manejo da cultura visando produtividade de rizomas, rendimento de fécula e amido de araruta. Os fatores avaliados foram diferentes níveis de irrigação, sistemas de plantio e de densidades de plantas. O delineamento experimental foi de blocos casualizados no ensaio de campo e inteiramente casualizados para as análises laboratoriais. Mediante os tratamentos,

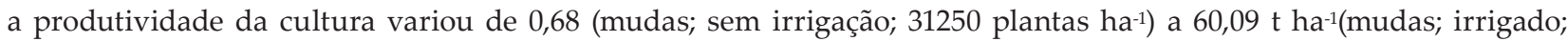
31250 plantas ha-1), enquanto que a produção de amido foi de 50 a $6.350 \mathrm{~kg} \mathrm{ha}^{-1}$. A maior produtividade de rizomas foi obtida em plantas produzidas por mudas juntamente com a maior densidade de plantas, e a maior produção de fécula e amido de araruta foi extraída de rizomas oriundos de plantas produzidas por mudas, sem uso de irrigação e com

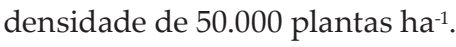

Palavras-chave: Maranta arundinacea L., hortaliças não convencionais, amido, resgate. 


\section{INTRODUCTION}

The arrowroot (Maranta arundinacea L.) is an herbaceous, perennial and rhizomatous plant belonging to the order Zingiberales, family Marantaceae, also known as maranta. The species is considered rustic with a rich and mycorrhizal root system. Its center of origin is probably Latin America and found natively in the Venezuelan forests (Ferrari et al., 2005; Valdes Restrepo et al., 2010). The starch extracted from the rhizomes of the plant is an alternative source of carbohydrate for consumption or raw material used in the food and non-food industry. Some researchers indicate that it is possible to make a layer of arrowroot starch in order to coat fruits and vegetables to increase post-harvest. It is a product appreciated for its medicinal properties in the treatment of gastrointestinal disorders, as well as being an easily digested starch in the human body due to the absence of gluten (Maulani \& Hidayat, 2016).

Because of its differentiated properties, the arrowroot starch reaches a higher price on the international market than similar products such as starch from maize, rice, wheat, oats, barley, manioc and potatoes. This is an excellent opportunity, given that the food industry is facing the difficulties of commercialization of modified starches for use in food. This fact has led the food, textile, chemical and pharmaceutical industries to search for natural starches with properties that meet market requirements such as the starch from arrowroot (Monteiro \& Peressin, 2002; Ferrari et al., 2005) increasing demand for this product.

Preliminary studies have shown that the yield of the arrowroot starch as well as its physicochemical properties are related to crop management, as well as the post-harvest handling of rhizomes (Leonel, 2007). Although Brazil, due to the climatic conditions, presents great potential to produce arrowroot starch, this crop is underutilized, since the cultivation is restricted to certain localities without the use technologies. As it is considered a rustic crop without great impact, the study on basic technologies such as fertilizer use, planting density, irrigation, among others, has been neglected, disregarding the potential impact of arrowroot starch in the national and international market.
Considering the potential relevance of arrowroot starch to the agribusiness, especially for family agriculture (Vieira et al., 2015), it is of fundamental importance the rescue of the species and consequently studies to encourage their production, since there are no available technical information regarding the recommendations of crop management such as fertilization, spacing, irrigation, pest control, diseases and weeds and their effects in the production of starch (Souza et al., 2016).

In view of the above, due to the lack of national and international scientific results to support the cultivation of arrowroot, the objective was to define adequate practices of crop management aiming increase the productivity the rhizome for the yield the starch of arrowroot.

\section{MATERIAL AND METHODS}

The experiment was conducted between October 2014 and August 2015, in the experimental area of the Olericulture Sector of the Department of Agriculture of the Federal University of Lavras (UFLA) in Lavras, south of the State of Minas Gerais, Brazil, which is located at the latitude $21^{\circ} 14^{\prime} \mathrm{S}$, longitude $45^{\circ} 00^{\prime} \mathrm{W}$ and altitude $918,8 \mathrm{~m}$. The climate of the region, according to the climatic classification of Köppen, is Cwa (mesothermal) with dry winters and rainy summers (Brasil, 1992). During the experiment, in the region, the average air temperature was $21.2^{\circ} \mathrm{C}$, and the minimum and maximum averages were $16.6^{\circ} \mathrm{C}$ and $27.7^{\circ} \mathrm{C}$, respectively. The total rainfall was $1105.6 \mathrm{~mm}$, with the wettest month being November with a level of $249.4 \mathrm{~mm}$ and the driest month being July with a level of $1.7 \mathrm{~mm}$. The climatic data of the experimental area during the field stay are shown in Figure 1.

Three factors were studied: plant material (PM), ways of irrigation (I) and planting density (PD). Each factor contained two specific categories (PM: rhizomes planted directly in the field and seedlings formed in polythene bags, in a screened and later taken to field; I: irrigated and without irrigation; PD: 31250 and 50000 plants ha-1). Therefore, eight treatments in the $2 \times 2 \times 2$ factorial scheme, in a randomized block design (DBC) with four replicates, each replicate being one block. Each plot had 18 plants and, to avoid the influence on 


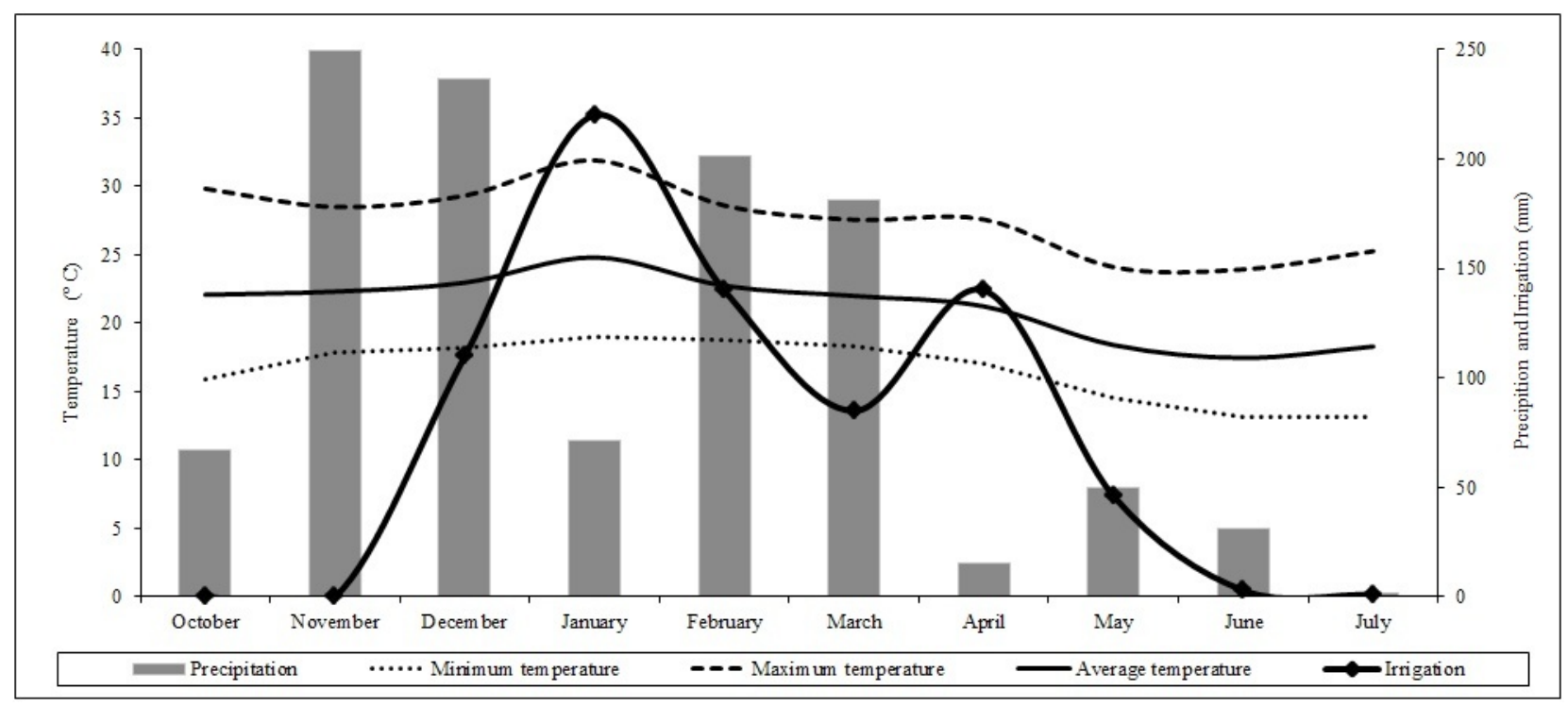

Figure 1 - Climatic data of the Lavras Meteorological Station and amount of water used in the irrigation of the arrowroot experiment in the agricultural years of 2014 and 2015.

the portion of the treatments applied in the neighboring plots, the bordering effect was considered, thus containing four useful plants per plot.

The soil preparation was done in a conventional way with a plowing and two harrows and the beds were raised with a bedtiller in the dimensions of 1.25 meters wide by 0.25 meters high. The soil of the experimental area is classified as Dystroferric Red Latosol and characteristics of the topsoil layer of 0 to $20 \mathrm{~cm}$ are presented in Table 1 . Based on the soil chemical analysis, liming was performed using $0.24 \mathrm{t} \mathrm{ha}^{-1}$ of limestone (PRNT $100 \%$ ). The fertilization of plantation incorporated to the pit was carried out. Hereafter, 75 days after planting, the top dressing was applied near the plant with superficial incorporation, according to recommendations adapted for tuberous (Ribeiro et al., 1999), with ammonium sulfate, single super-phosphate and potassium chloride, the amounts of fertilizers varied according to plant density ha ${ }^{-1}$. The cultural treatments were carried out according to the need of the culture, like the weeding, the combat to the leaf-cutting ants and heaping realized in the beginning of January.

In the planting, arrowroot rhizomes of the "Seta" cultivar were used, originated from UFLA's Non-Conventional Vegetables Germplasm collection, since there is no propagation of the species by seeds in tropic regions (Souza et al., 2016). The rhizomes were cut containing about 30 to $60 \mathrm{~g}$, with at least three meristems, to generate each plant. The plants were irrigated on a daily basis.

Table 1 - Physical-chemical analysis of the soil performed in the experimental area

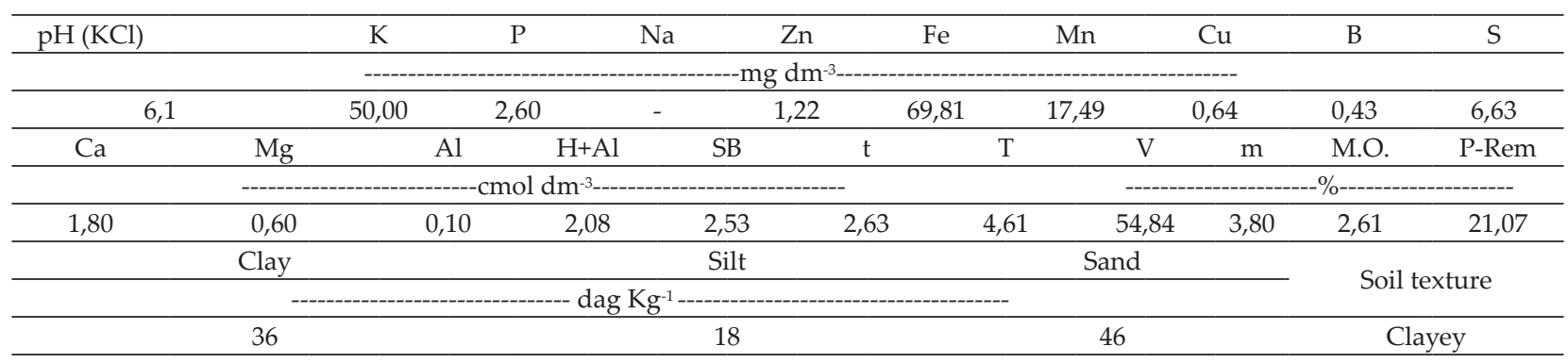


Both the seedlings and the rhizomes in the field were planted at the beginning of October. The seedlings were produced in polyethylene bags $\left(5.292 \mathrm{~cm}^{3}\right)$ filled in the proportion of $60 \%$ commercial substrate Rohrbacher (organic compounds, pine bark and vermiculite), 30\% sifted earth and $10 \%$ sand. The polyethylene bags were kept in a greenhouse until the transplanting occurred approximately 70 days after planting, when the seedlings presented four definitive leaves. In this initial period, all the materials were irrigated by spraying, daily, to keep the soil always moist during the budding phase until the plants reached around $20 \mathrm{~cm}$ (Zárate \& Vieira, 2005).

Two levels of planting density were used, corresponding to the spacing of $40 \mathrm{~cm}$ between rows and $80 \mathrm{~cm}$ between plants, about 3 plants $\mathrm{m}^{-2}$ and the spacing of $40 \mathrm{~cm}$ between rows and $50 \mathrm{~cm}$ between plants, resulting in 5 plants $\mathrm{m}^{-2}$, with part of the experiment being irrigated by drip and part without irrigation. An irrigation system with lateral lines composed of NAAN PC dripping tubes $16 \mathrm{~mm}$ in diameter, with emitters spaced between $30 \mathrm{~cm}$ and flow of $1.6 \mathrm{~L} \mathrm{~h}^{-1}$, was used, allowing the wet surface to form a continuous band along the planting line. The irrigation was carried out at intervals of two days with a mean leaf of $7 \mathrm{~mm}$, depending on the rainfall, being suspended 60 days before harvest, aiming at the best quality of the rhizomes. There were variations in the irrigation frequency with months of constant precipitations and months with days of intense precipitation and long periods of drought. Therefore, the irrigation was adapted according to the precipitation frequency (Figure 1).

The harvest was performed at 309 days after planting, when the aerial part of the plants had more than $60 \%$ of leaf senescence. The following variables were evaluated: stem diameter $(\mathrm{mm})$ with pachymeter, plant stand $(\%)$ and height $(\mathrm{cm})$ throughout the crop cycle; total productivity $\left(\mathrm{t} \mathrm{ha} \mathrm{H}^{-1}\right.$ ) and rhizomes weight $(\mathrm{g})$ measured in precision scales; amount of rhizomes (unity plant ${ }^{-1}$ ); and rhizome size according to Zárater \& Vieira (2005) in three classes: large $(>20 \mathrm{~cm})$, medium (12 to $20 \mathrm{~cm})$ and small $(<12 \mathrm{~cm})$.

After the harvest, the rhizomes of each treatment were taken to the Laboratory of Grains, Roots and Tubers of the Department of Food Science of the Federal University of Lavras for starch extraction. Arrowroot rhizomes were washed to remove adhered soil and unnecessary parts and then selected for lack of injuries and deformation. Afterwards, they were cut into $0.5 \mathrm{~cm}$ thick slices and weighed. In the laboratory analyzes, the completely randomized design was adopted, with three replicates for each treatment.

For the starch extraction, the rhizomes of each treatment were triturated with distilled water, in the proportion of 1: 1 , in an industrial blender (Lucre, model C4, Brazil), and then filtered into organza fabric. The rhizome residue was stored, while the suspension was rested ( \pm 16 hours) in a refrigerated environment $\left( \pm 5^{\circ} \mathrm{C}\right)$. The supernatant was discarded and the precipitated starch was re-suspended with distilled water to be discarded again. This starch suspension and settling procedure was repeated until the product had starch characteristic white color and fine texture. The material was then dried in a forced air circulation oven at $45^{\circ} \mathrm{C}$ until reaching a constant mass and cooled to room temperature. Afterwards, it was reduced to powder, using gral and pistil, sieved in a sieve of $0.350 \mathrm{~mm}$ and, finally, packed in a bottle until its later use (Daiuto \& Cereda, 2003).

The starch was identified by washing for the removal of sugars, autoclaving, neutralization, deproteinization and determination by reading in a spectrophotometer at $510 \mathrm{~nm}$, according to the norms of the Adolfo Lutz Institute (2008).

The results were analyzed with observations of means and standard deviation, and the evaluations submitted to analysis of variance. For the quantitative effects the data were adjusted to a regression model. The experimental precision was analyzed using the coefficient of variation $(\mathrm{CV})$ and the statistical analysis performed with the aid of SISVAR® software (Ferreira, 2011).

\section{RESULTS AND DISCUSSION}

According to the analysis of variance (Table 2), the interaction between all the agronomic managements adopted in the experiment (PM x I x PD) was not significant for the evaluated characteristics. 
However, significant double interactions were observed for the characteristics of plant stand, productivity, weight and rhizome size.

The estimation of the coefficient of variation of greater magnitude was observed for the rhizome size character, $44.83 \%$, and the lowest for the plant stand with $5.37 \%$. Good experimental accuracy is critical to the success of field experiments. Pimentel-Gomes (2009), when studying the CVs of agricultural trials, classified them as it follows: low when less than $10 \%$; average, between 10 and $20 \%$; high, when they are between 20 and 30\%; and very high, when they are higher than $30 \%$.

The stem diameter, regardless of agronomic management adopted and the interactions between the factors, did not present differences between the treatments, with an average value of $7.62 \mathrm{~mm}( \pm$ $0.56)$. However, for the plant stand, it was observed that the arrowroot produced by seedlings showed a constant stand during the crop development cycle and treatments with plants derived from rhizomes planted directly in the field varied throughout the evaluated months (Figure 2).

In the plant stand there was interaction between $\mathrm{PM} \times \mathrm{PD}$, the treatments produced by seedlings in any plant density (31250 or 50000 plants ha ${ }^{-1}$ ) presented a stand with a mean of $97.23 \%( \pm 0.98)$ of live plants in the experimental area, whereas in the treatments produced by direct rhizome in the field in a larger spacing, the losses in the stand were of $33.33 \%$. Possibly the irregularity may be due to phytopathogens, because at the planting, the rhizomes used were cut, and in contact with

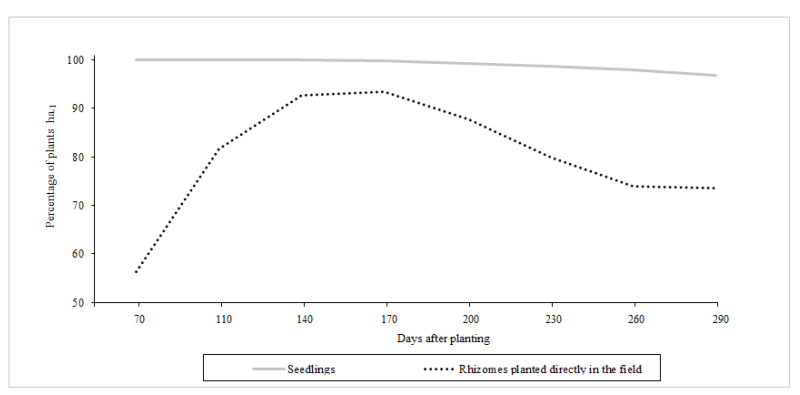

Figure 2 - Plant stand along the vegetative cycle of the crop according to the type of planting.

the soil occurs the development of diseases caused by fungus and/or bacteria.

The plant height was influenced by two factors: plant material and irrigation. The treatments with higher height were those produced by seedlings $(142.99 \mathrm{~cm})$ with an increase of $38.81 \%$, when compared to the plants derived from direct rhizomes in the field. In the irrigated treatments, the increase was $11.46 \%$ higher than those conducted without irrigation (Figure 3). The higher the height of the plant, the greater the leaf area tends to be and consequently the greater the conversion of photoassimilates, as well as the increased ability of the crop to compete with weeds (greater plant height has a greater capacity to suppress the growth of competing plants).

In the plant material in which the rhizomes are planted directly in the field, despite the precocity of the production, the non-injury of the roots and with no stress occurring in the adaptation phase of the seedlings after the transplant, there may be

Table 2 - F value calculated by the analysis of variance and coefficient of variation of the agronomic characteristics evaluated in the experiment

\begin{tabular}{|c|c|c|c|c|c|c|c|c|c|}
\hline \multirow[b]{2}{*}{ Agronomic characteristics } & \multicolumn{8}{|c|}{ VARIABLE FACTORS } & \multirow[b]{2}{*}{ CV $(\%)$} \\
\hline & Treatments & I & PM & PD & I x PM & I x PD & PM x PD & I x PM x PD & \\
\hline Stem diameter $(\mathrm{mm})$ & $0,85^{\text {ns }}$ & $0,59^{\text {ns }}$ & $1,46^{\mathrm{ns}}$ & $0,06^{\mathrm{ns}}$ & $0,09^{\text {ns }}$ & $2,38^{\text {ns }}$ & $1,38^{\text {ns }}$ & $0,02^{\text {ns }}$ & 15,90 \\
\hline Plant stand & $44,47^{* *}$ & $2,31^{\mathrm{ns}}$ & $265,45^{* *}$ & $5,71^{\mathrm{ns}}$ & $0,43^{\text {ns }}$ & $2,31^{\mathrm{ns}}$ & $10,62^{*}$ & $2,31^{\mathrm{ns}}$ & 5,37 \\
\hline Plant height (cm) & $28,53^{* *}$ & $14,15^{* *}$ & $222,17^{* *}$ & $0,27^{\mathrm{ns}}$ & $0,20^{\text {ns }}$ & $0,44^{\text {ns }}$ & $5,97^{\mathrm{ns}}$ & $0,00^{\text {ns }}$ & 9,14 \\
\hline Productivity $\left(\mathrm{t} \mathrm{ha}^{-1}\right)$ & $141,62^{* *}$ & $19,26^{* *}$ & $855,56^{* *}$ & $32,07^{* *}$ & $7,38^{*}$ & $7,30^{*}$ & $68,19^{* *}$ & $1,56^{\mathrm{ns}}$ & 17,16 \\
\hline Number of rhizomes (unit planta ${ }^{-1}$ ) & $33,73^{* *}$ & $2,79^{\text {ns }}$ & $222,87^{* * *}$ & $8,01^{* *}$ & $0,07^{\mathrm{ns}}$ & $0,04^{\mathrm{ns}}$ & $0,76^{\mathrm{ns}}$ & $1,59^{\text {ns }}$ & 25,11 \\
\hline Mass of rhizomes $(\mathrm{g})$ & $19,43^{* *}$ & $3,76^{\mathrm{ns}}$ & $61,89^{* *}$ & $2,13^{\text {ns }}$ & $9,04^{* *}$ & $0,72^{\text {ns }}$ & $2,49^{\text {ns }}$ & $4,31^{\mathrm{ns}}$ & 19,43 \\
\hline Length of rhizomes & $0,22^{\text {ns }}$ & $0,00^{\mathrm{ns}}$ & $0,73^{\text {ns }}$ & $0,03^{\text {ns }}$ & $0,36^{\text {ns }}$ & $0,27^{\mathrm{ns}}$ & $0,08^{\text {ns }}$ & $0,04^{\mathrm{ns}}$ & 44,83 \\
\hline Rhizomes $(>20 \mathrm{~cm})$ & $3,05^{*}$ & $3,37^{\mathrm{ns}}$ & $7,10^{* * *}$ & $0,52^{\text {ns }}$ & $6,27^{*}$ & $0,71^{\text {ns }}$ & $0,05^{\text {ns }}$ & $3,37^{\mathrm{ns}}$ & 8,53 \\
\hline Rhizomes (12 a $20 \mathrm{~cm}$ ) & $3,06^{*}$ & $0,01^{\mathrm{ns}}$ & $0,33^{\text {ns }}$ & $0,24^{\text {ns }}$ & $0,38^{\text {ns }}$ & $18,50^{* *}$ & $1,86^{\mathrm{ns}}$ & $0,10^{\text {ns }}$ & 8,73 \\
\hline Rhizomes $(<12 \mathrm{~cm})$ & $2,10^{*}$ & $3,43^{\text {ns }}$ & $5,79^{*}$ & $0,55^{\text {ns }}$ & $0,69^{\text {ns }}$ & $1,93^{\text {ns }}$ & $1,45^{\text {ns }}$ & $0,86^{\mathrm{ns}}$ & 21,44 \\
\hline
\end{tabular}

I: Ways of irrigation; PM: Plant material; PD: Planting density; CV: Coefficient of variation; ns: not significant; ${ }^{* *}$ significant at $1 \%$ probability; ${ }^{*}$ significant at $5 \%$ probability. 


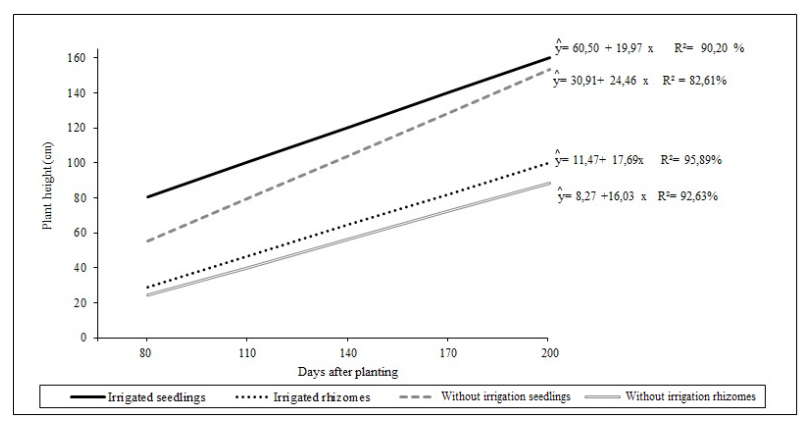

Figure 3 - Plant growth of arrowroot over the evaluated months.

problems related to the uniformity of germination and the growth of the plants, compromising the final stand and perhaps the productivity (Filgueira, 2013). So, the production of seedlings has been a viable alternative to minimize possible problems, besides the advantage of hindering the development of weeds due to the closure of the stand.

Throughout the experiment, during the hours with higher air temperature, the plants conducted in without irrigation presented leafroll. Leaf movement is a mechanism to deal with stress caused by environmental factors, and is generally associated with reduced transpiration so that the plant does not suffer permanent wilt. However, climate change, especially those related to water and thermal stress can limit plant growth, reducing carbon and energy consumption, altering the allocation of photoassimilates by plant organs (Kadioglu et al., 2012; Taiz \& Zeiger, 2013).

Arrowroot productivity was influenced by all the factors studied, in which, irrigation per se promotes an increase in rhizome production of $23.53 \%$ in comparison to the without irrigation system. Plants grown by seedlings showed a $94.04 \%$ increase in relation to no-till in the field, while in the density of 50000 plants ha-1 $^{-1}$ the productivity gains were $29.30 \%$ higher than those in the density of 31250 plants ha-1.

The double interactions were also significant for this characteristic, being necessary to perform the splitting between the factors. For I x PD, it was observed that without irrigation treatments and density of 31250 plants ha ${ }^{-1}$ had the lowest productivity $\left(15.32 \mathrm{t} \mathrm{ha}^{-1}\right)$, but irrigated treatments showed no difference between planting densities, with average $28.31 \mathrm{t} \mathrm{ha}^{-1}( \pm 3.17)$. In the PM $x$ PD interaction, planting of seedlings in the density of 50000 plants ha-1 was the most productive $\left(57.70 \mathrm{t} \mathrm{ha}^{-1}\right)$ while the rhizomes planted directly in the field, regardless of the density of plants per area, showed lower productivity mean of $2.81 \mathrm{tha}^{-1}( \pm 2.78)$. In the PMx I interaction, planting of seedlings with irrigation presented the highest productivity $52.54 \mathrm{t} \mathrm{ha}^{-1}$ and the lowest $1.55 \mathrm{t} \mathrm{ha}^{-1}$ for treatments planted by rhizomes directly in the field without irrigation.

It is noteworthy that, to increase production, the use of seedlings and of spacing of $40 \mathrm{~cm}$ between rows and $50 \mathrm{~cm}$ between plants gives better results, without considering the adopted of irrigation. The treatments with these characteristics obtained an average yield of $57.70 \mathrm{tha}^{-1}( \pm 3.38)$, a production gain of extreme relevance, as Zárate \& Vieira (2005) obtained an average yield of $18.53 \mathrm{t} \mathrm{ha}^{-1}$ working with "Common" arrowroot rhizomes planted directly in the field, with density of 99000 plants ha-1 with irrigation, Vieira et al. (2015) had a similar result, $17.82 \mathrm{t} \mathrm{ha}^{-1}$, planting 'Viçosa' arrowroot rhizomes planted directly in the field spaced $0.80 \mathrm{~cm}$ between plants and $0.40 \mathrm{~cm}$ in the rows, with a density of 31250 plants ha-1 and dry farming.

The production of rhizomes is directly correlated with agronomic characteristics such as plants height and stand. For these characters, a strong and positive correlation was observed, 0.83 and 0.84 , respectively. The number and mass of rhizomes were significantly influenced by the plant material, promoting an increase of approximately 80 and $40 \%$, respectively, when the plants were obtained by seedlings.

Planting density affected the number of rhizomes, with denser spacing ensuring a higher number of rhizomes per plant. Data with the potato crop corroborate, partially, with the present study, that plants conducted in smaller spacing provide a greater number of tubers, due to the greater competition among the plants, but without effect on productivity, being the increase in the number of tubers not sufficient to increase production, due to the increase in the number of small tubers (Queiroz et al., 2013). However, arrowroot did not present this expected behavior, planting density 
did not affect the rhizome mass with a mean value of $74.75 \mathrm{~g}$ rhizomes $^{-1}( \pm 5.30)$, which allowed to reach higher production in planting with higher populational density.

The results for length of rhizomes, when evaluated together, presented a very high coefficient of variation and without any interference of the factors under study. However, it was necessary to separate the rhizomes by size classes to verify the performance of each factor. Rhizomes of large size $(>20 \mathrm{~cm})$ and small size $(<12 \mathrm{~cm})$ were significantly influenced by the plant material, being larger in plants originated through seedlings. In relation to the rhizomes with size between 12.01 and $20 \mathrm{~cm}$ there was $\mathrm{WH}$ x PD interaction, with a mean length of $16.21 \mathrm{~cm}$ $( \pm 1.25)$. The handling with lower population density and submitted to irrigation obtained smaller size compared to the nursery rhizomes, and in condition of greater density the behavior was opposite.

Under similar cultivation conditions Zárate \& Vieira (2005) obtained a mean mass of $77.69 \mathrm{~g}$ rhizome $^{-1}$ and a length of $22.18 \mathrm{~cm}, 15.55 \mathrm{~cm}$ and $7.51 \mathrm{~cm}$ for medium and small-sized rhizomes, respectively, similar characteristics to that found in this study, mean mass of $74.75 \mathrm{~g}^{\text {rhizome }}{ }^{-1}$ and length of $25.71 \mathrm{~cm}, 16.20 \mathrm{~cm}$ and $8.90 \mathrm{~cm}$ for the large, medium and small classes. These results allow to observe that these characters are intrinsic to the used rhizomes and the way of conducting the crop (Zárate et al., 1999).

After the harvest, the rhizomes were processed, as the commercial product for the cultivation of arrowroot is the starch. In view of this, it is essential to evaluate the yield and the industrial and nutritional properties of the obtained product. The extraction of the starch is a way to conserve the nutritional characteristics of the rhizome, because it is a product powder, therefore it presents / displays low water activity and thus long storage period. For industry, these results are of fundamental importance as they are associated with the final cost of the product (Streck et al., 2014).

Table 3 shows the combined effect of irrigation and plant material, as well as the plant material and plant density in the starch yield. For starch, there was a combined effect of the three analyzed factors (I x PM x PD).

In the unfolding of the interactions it is correct to state that for the extraction of starch from the rhizomes, in the interaction of I x PM, the products from seedlings and irrigation system have a reduction in yield of $29.53 \%$ compared the other crop managements, while in the interaction of PD x PM there was a decreased yield by $25.50 \%$ when coming from seedlings and density of 31250 plants $\mathrm{ha}^{-1}$. Thus, the treatment that presents these factors in common (produced by seedlings, irrigation and greater spacing) has the lowest extraction yield, from $6.61 \mathrm{~g}$ of starch to $100 \mathrm{~g}$ of rhizome, and the most efficient treatments have an average extrac-

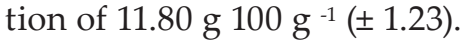

The starch content did not differ between treatments, with an average value of $86.09 \mathrm{~g}$ of starch to $100 \mathrm{~g}( \pm 5.09)$, close to the results found by Ferrari

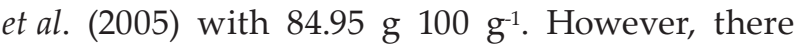
was a triple interaction that affected the amount of arrowroot starch, where the starch obtained from rhizomes produced under conditions of greater spacing under irrigation and from rhizomes directly in the field presented higher starch content. This is probably due to less competition between the plants for light and consequently to the greater production of photoassimilates, among them the starch.

Table 3 - Value of F calculated by the analysis of variance and coefficient of variation of the analyzes of fecula yield ( $\left.\mathrm{g} 100 \mathrm{~g}^{-1}\right)$ and amount of starch $\left(\mathrm{g} 100 \mathrm{~g}^{-1}\right)$ in arrowroot fecula

\begin{tabular}{|c|c|c|c|c|c|c|c|c|c|}
\hline \multicolumn{10}{|c|}{ VARIABLE FACTORS } \\
\hline Analysis & Treatments & I & PM & PD & I x PM & I x PD & PM x PD & I x PM x PD & CV (\%) \\
\hline Starch yield & $4,19^{* *}$ & $3,01^{\text {ns }}$ & $2,26^{\text {ns }}$ & $1,96^{\mathrm{ns}}$ & $12,69^{* *}$ & $0,09^{\text {ns }}$ & $8,71^{* *}$ & $0,64^{\text {ns }}$ & 17,23 \\
\hline Amount of starch & $14,31^{\mathrm{ns}}$ & $0,88^{\text {ns }}$ & $1,19^{\text {ns }}$ & $61,17^{* *}$ & $14,04^{* *}$ & $7,33^{* *}$ & $9,52^{* *}$ & $6,03^{* *}$ & 2,21 \\
\hline
\end{tabular}

I: Ways of irrigation; PM: Plant material; PD: Planting density; CV: Coefficient of variation; ns: not significant; ${ }^{* *}$ significant at $1 \%$ probability; ${ }^{*}$ significant at $5 \%$ probability. 
For there to be significant decreases in the average starch percentages of the roots, factors that have a strong impact on the normal development of the plants are necessary. One of the factors is competition with weeds or with the crop itself (Filho et al., 2003).

With the association of rhizome productivity data, yield on the extraction and amount of starch it is possible to estimate the production by area. The treatment 2 (conducted without irrigation, by seedlings and density of 50000 plants ha ${ }^{-1}$ ) presented a

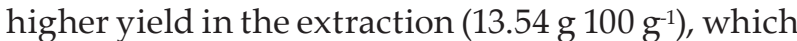
reached a yield of 55.31 tha $^{-1}$ rhizomes, with 7.49 tha $^{-1}$ starch, and $6.35 \mathrm{t} \mathrm{ha}^{-1}$ starch. In addition, the irrigated treatment, produced by seedlings and in the density of 50000 plants ha- ${ }^{-1}$, which despite the

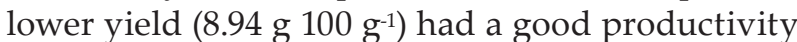
in the field $\left(60.09 \mathrm{t} \mathrm{ha}^{-1}\right)$ that compensated the final starch production with $5.37 \mathrm{tha}^{-1}$ and $4.40 \mathrm{t} \mathrm{ha}^{-1}$ of starch (Figure 4) also deserves to be mentioned.

It should be noted that at the end of the month of December until mid-January there was a great period of drought, atypical for the region, in fact inferring the productivity of the crop. In these climatological conditions, to associate the planting of seedlings in denser spacing, aiming at higher planting density, confers better results for the components of crop production. The use of irrigation allowed to achieve higher productivity in the field, however, the extraction of starch yield was lower, if the cost of production of irrigation is considered, the without irrigation system is the most indicated.

\section{CONCLUSIONS}

The production of 'Seta' arrowroot rhizomes is influenced by the plant material, irrigation and plant density. The highest rhizomes yield was obtained in plants produced by seedlings with the highest density of 50000 plants ha-1.

The highest starch yield was obtained from rhizomes originating from plants produced by seedlings, without irrigation use and density of 50000 plants ha-1 .

\section{ACKNOWLEDGMENTS}

The authors are grateful to the Minas Gerais Research Support Foundation (FAPEMIG), the National Council for Scientific and Technological Development $(\mathrm{CNPq})$, the Coordination of Personal Improvement of Higher Education (Capes ( MEC), the Federal University of Lavras (UFLA), the Teaching, Research and Extension Support Foundation (FAEPE) and the Foundation for Scientific and Cultural Development (Fundecc).

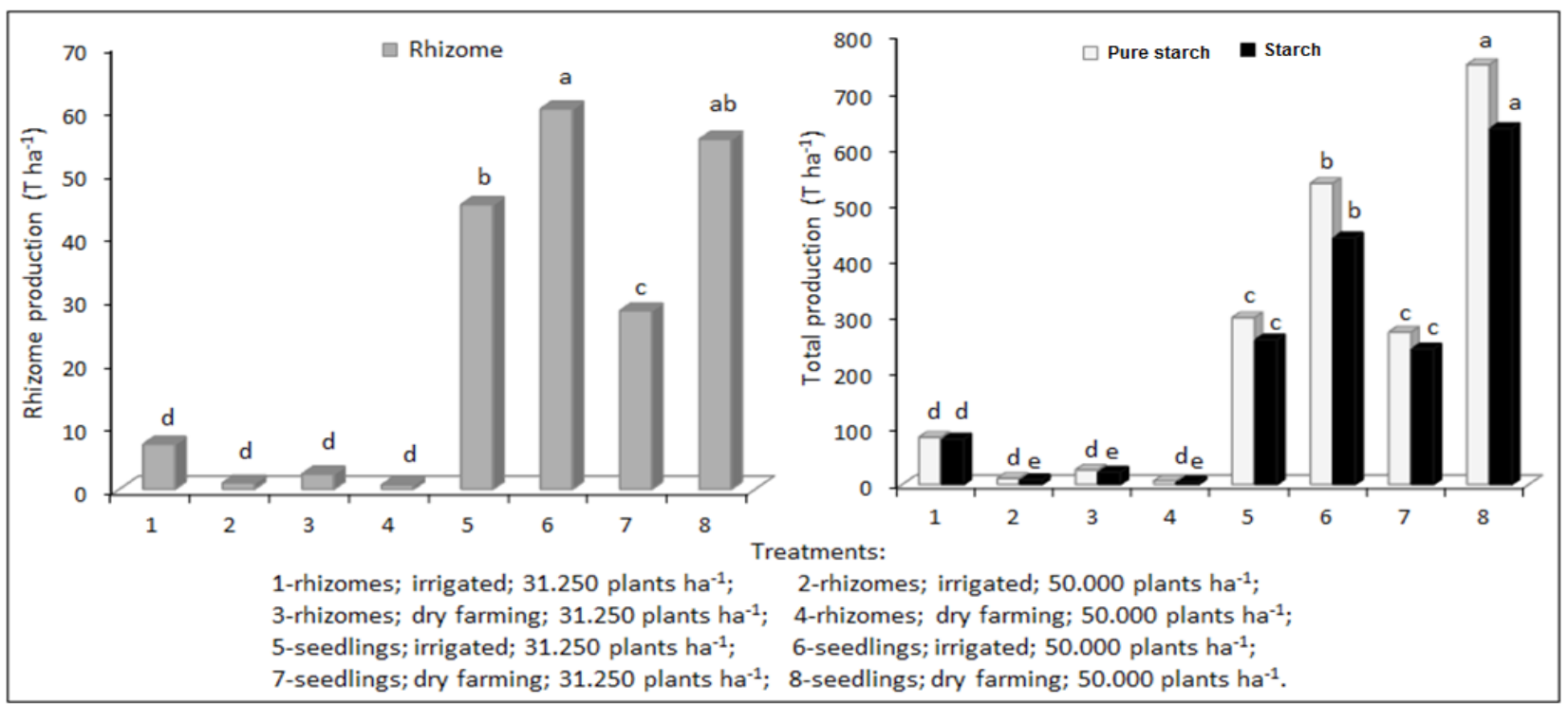

Figure 4 - Estimated value for rhizomes, pure starch and arrowroot starch yield through different planting techniques. 


\section{REFERENCES}

Brasil (1992) - Normais climatológicas: 1961-1990. Ministério da Agricultura e da Reforma Agrária. Departamento Nacional de Meteorologia. Brasília, DF, 84 p.

Daiuto, E.R. \& Cereda, M.P. (2003) - Amido como suporte na desidratação por atomização e em microencapsulamento. In: Cereda, M.P. \& Vilpoux, O.F. (Eds.) - Tecnologia, usos e potencialidades de tuberosas amiláceas sul americanas. São Paulo: Fundação Cargill, p. 449-475.

Ferrari, T.B.; Leonel, M. \& Sarmento, S.B.S. (2005) - Características dos rizomas e do amido de araruta (Maranta arundinacea) em diferentes estádios de desenvolvimento da planta. Brazilian Journal of Food Technology, vol. 8, n. 2, p. 93-98.

Ferreira, D.F. (2011) - Sisvar: a computer statistical analysis system. Ciência e Agrotecnologia, vol. 35, n. 6, p. 1039-1042. http://dx.doi.org/10.1590/S1413-70542011000600001

Filgueira, F.A.R. (2013) - Novo manual de olericultura: agrotecnologia moderna na produção e comercialização de hortaliças. Universidade Federal de Viçosa: Empresa Júnior de Agronomia, 421 p.

Filho, A.G.; Strohhaecker, L. \& Fey, E. (2003) - Profundidade e espaçamento da mandioca no plantio direto na palha. Ciência Rural, vol. 33 n. 3, p. 461-467. http://dx.doi.org/10.1590/S0103-84782003000300011

Instituto Adolfo Lutz (2008) - Métodos físico-químicos para análise de alimentos. Instituto Adolfo Lutz, São Paulo. $1020 \mathrm{p}$.

Kadioglu, A.; Terzi, R.; Saruhan N. \& Saglam, A. (2012) - Current advances in the investigation of leaf rolling caused by biotic and abiotic stress factors. Plant Science, vol. 182, p. 42-48. https://doi.org/10.1016/j. plantsci.2011.01.013

Leonel, M. (2007) - Análise da forma e tamanho de grânulos de amidos de diferentes fontes botânicas. Ciência e Tecnologia de Alimentos, vol. 27, n. 3, p. 579-588. http://dx.doi.org/10.1590/S0101-20612007000300024

Maulani, R.R. \& Hidayat, A. (2016) - Characterization of the functional properties of hydroxypropylated and cross-linked arrowroot starch in various acidic $\mathrm{pH}$ mediums. International Journal of Technology, vol. 7, n. 1, p. 176-184. https://doi.org/10.14716/ijtech.v7i1.1226

Monteiro, D.A. \& Peressin, V.A. (2002) - Cultura da araruta. In: Cereda, M.P. (Ed.) - Agricultura: tuberosas amiláceas Latino Americanas. São Paulo: Fundação Cargill, vol. 2, p. 440-447.

Pimentel-Gomes, F. (2009) - Curso de estatística experimental. Piracicaba: FEALQ, 451 p.

Queiroz, L.R.M.; Kawakami, J.; Muller, M.M.L.; Umburanas, R.C. \& Eschemback, V. (2013) - Tamanho de tubérculo-semente e espaçamento na produtividade de batata em condições de campo. Comunicata Scientiae, vol. 4, n. 3, p. 308-315.

Ribeiro, A.C.; Guimarães, P.T.G. \& Alvarez, V.H. (1999) - Recomendações para o uso de corretivos e fertilizantes em Minas Gerais: 5o Aproximação. Comissão de fertilidade do solo do estado de Minas Gerais, 322 p.

Souza, D.C.; Silva, L.F.L.; Resende, L.V.; Costa, P.A.; Guerra, T.S.; Gonçalves, W.M. \& Pereira, T.A.R. (2016) - Conservação pós-colheita de araruta em função da temperatura de armazenamento. Magistra, vol. 28, n. 3/4, p. 403-410.

Streck, N.A.; Pinheiro, D.G.; Zanon, A.J.; Gabriel, L.F.; Rocha, T.S.M.; Souza, A.T. \& Silva, M.R. (2014) - Efeito do espaçamento de plantio no crescimento, desenvolvimento e produtividade da mandioca em ambiente subtropical. Bragantia, vol. 73, n. 4, p. 407-415. http://dx.doi.org/10.1590/1678-4499.0159

Taiz, L. \& Zeiger, E. (2013) - Fisiologia Vegetal. Artmed. 954 p.

Valdes Restrepo, M.P.; Ortiz Grisales, S. \& Sanchez, T. (2010) - Morfología de la planta y características de rendimiento y calidad de almidón de sagú. Acta Agronomica, vol. 59, n. 3, p. 372-380.

Vieira, J.C.B.; Colombo, J.N.; Puiatti, M.; Cecon, P.R. \& Silvestre, H.C. (2015) - Desempenho da araruta 'Viçosa' consorciada com crotalária. Revista Brasileira de Ciências Agrárias, vol. 10, n. 4, p. 518-524. http:// dx.doi.org/10.5039/agraria.v10i4a5271

Zárate, N.A.H.; Vieira, M.C. \& Griep, R. (1999) - Produção dos clones de cará Liso e Caramujo conduzidos em forma rasteira e tutorada. Horticultura Brasileira, vol. 17, n. 1, p. 45-48. http://dx.doi.org/10.1590/5010205361999000100012

Zárate, N.A.H. \& Vieira, M.C. (2005) - Produção da araruta "comum" proveniente de três tipos de propágulos. Ciência e Agrotecnologia, vol. 29, n. 5, p. 995-1000. http://dx.doi.org/10.1590/S1413-70542005000500012 